\title{
PENDIDIKAN KARAKTER DALAM PERSPEKTIF AL QUR'AN
}

\author{
Oleh : \\ Hamam Burhanuddin ${ }^{1}$ \\ Institut Agama Islam Sunan Giri Bojonegoro \\ hmmudin@gmail.com
}

\begin{abstract}
Character education consists of two words namely education and character. The meaning of character education according to Islam is a conscious effort made by educators to students to shape the personality of students who teach and shape morals, ethics, and a good sense of culture. The character that foster students'ability to make good and bad decisions and realize goodness that in everyday life by means of education, teaching, guidance and training which is guided by the Qur'an.

The basis of character education in Islam is the Qur'an the character of the Prophet Muhammad. Character education is very important at this time, because character will show who the really, character will determine how someone makes decisions, character determines attitudes, words and actions of someone, people who have good character, then the words and deeds will also be good, so all it will become a unified identity and personalize itself, making it easy to distinguish from other identities.

The purpose of character education is to form a person of character, because character is the base of goodness. People of good character will soon leave goodness and leave badness. Implementation of character education in Islamic education institutions varies greatly depending on the policies of these educational institutions.
\end{abstract}

Keywords: Pendidikan Karakter, Al Qur'an

\section{A. INTRODUCTION}

The definition of character in the etymological comes from the Greek, namely characin that means, "to engrave". The word "to engrave" can be translated to carve, paint, carve, or carve ${ }^{2}$. In the Big Indonesian Dictionary ${ }^{3}$, the word "character" is defined by the nature, mental characteristics, character or character that distinguishes one person from another and character. In the MoNE language center (2008) as quoted by Marzuki, characters can also mean people who have personality and good behavior. ${ }^{4}$

\footnotetext{
${ }^{1}$ Dosen Institut Agama Islam Sunan Giri Bojonegoro

2 Marzuki, Pendidikan Karakter Islam, (Jakarta: Amzah, 2015), 4.

${ }^{3}$ Kamus Besar Bahasa Indonesia, 2012, 34.

${ }^{4}$ When viewed in the context of education a lot of immoral behavior occurs, including cases of brawls between students in several schools, the circulation of obscene videos where the perpetrators are students, drug abuse and other illegal drugs, even some young women are willing to sell "girlhood" in order to buy handphone (cellphone), buy good clothes or treat friends. Based on data from the Indonesian Child Protection Commission (KPAI, 2003) states as many as $32 \%$ of adolescents aged 14 to 18 years in major cities of Indonesia (Jakarta, Surabaya, and Bandung) have had sex.
} 
The character ${ }^{5}$ interpreted as a personality. ${ }^{6}$ Personality is a characteristic, characteristic in a person. Character can be formed through the environment, for example the family environment in childhood or innate from birth. There are those who think the good and bad of human character are innate. If the innate soul is good, then humans will be of good character, which opinion is true, and then character education is of no use, because it will not be possible to change people's character. ${ }^{7}$

Meanwhile, there are also those who think character can formed and pursued. In this opinion implies that character education is very useful to change humans into people of good character.

The character is a means temperament or deeds is done, habits, or can be interpreted as character, namely the nature of the human mind that affects all thoughts and behavior or personality.

People who act dishonest, cruel or greedy are said to be people of bad character, while people who behave honestly and are helpful are said to be people of noble character ${ }^{8}$ In the Qur'an, humans are creatures with various characters. In a large framework, humans have two opposing characters, good and bad characters. As the word of God in the ash-Sham verses 8-10.

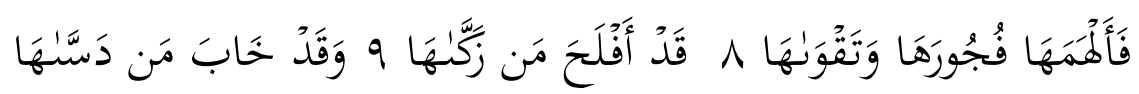

"So Allah inspired the soul (the path) of its evil and fear. Blessed are those who purify the soul. And indeed it is for those who profane it. " (Q.S. Ash-Sham: 810).

Character can be interpreted also with the values of human behavior related to God Almighty, self, fellow human beings, the environment and nationality manifested in thoughts, attitudes, feelings, words and deeds based on religious norms, laws, karma , culture and customs that apply in their environment.

While in terminology, the meaning of character is stated by Thomas Lickona, which states that the character is "A reliable inner disposition to respond to

Another case based on data from the National Narcotics Agency (BNN) until 2008 drug users in Indonesia reached 3.2 million people. Of this number $32 \%$ are students.

${ }^{5}$ Philosophically, character education is the most rational and actual study of science because it discusses human behavior that is timeless by changing times. Besides character education has a normative basis, according to Hamdani Hamid \& Beni Ahmad Saebani, among others: a) Derived from the teachings of Islam, namely from the Qur'an and As-Sunnah, also applies to the teachings of other religions that are widely followed by humans. b) Cultural customs or norms. c) Philosophical views form the view of life and the struggle principle of a society or a nation. d) Legal norms that have been enacted by the State in the form of constitutions, laws and other laws and regulations that are forcing and binding to human morals.

${ }^{6}$ Hamam Burhanuddin, "Membangun Karakter Bangsa Melalui Pendidikan Islam," At-

Tajdid : Jurnal Ilmu Tarbiyah, 2014.

${ }^{7}$ Ajat Sudrajat, “Mengapa Pendidikan Karakter?," Jurnal Pendidikan Karakter 1, no. 1 (2011): 47-58, https://doi.org/10.21831/jpk.v1i1.1316.

${ }^{8}$ Amirullah Syarbini, Pendidikan Karakter Berbasis Keluarga, (Jakarta: Arruz Media, 2012), 15. 
situations in a morally good way." Furthermore, Lickona said, "Character so conceived has three interrelated parts: moral knowing, moral feeling and moral behavior". According to Lickona, noble character (good character) includes knowledge about goodness (moral knowing), then raises commitment (intention) towards goodness (moral feeling) and finally actually does goodness (moral behavior). In other words, character refers to a series of knowledge (cognitive), attitudes and motivations, as well as behaviors and skills. ${ }^{9}$

According to Islamic terminology, the understanding of character has a closeness of understanding with the understanding of morality ${ }^{10}$. According to etymology, the word moral come from Arabic (اخلاق), the plural form of the mufrad khuluq (خلق), which means "character." Synonyms are ethics and morals. Ethics comes from Latin, ethos that means habit. Moral also comes from Latin as well, Mores which means habit.

In the sentence khuluq contains aspects of conformity with the words of the khalakun (اخلق) which means events, and closely related khalik (خلق)) which means creation and creature (مخلوق) which means created. ${ }^{11}$

According to Abdul Hamid states, morality is all educated human nature. ${ }^{12}$ Understanding these statements can be understood that the nature or potential brought by humans from birth, meaning that this potential depends on how the formation and formation. If the effect is positive, then just like character education, moral education, outputs are noble morals and vice versa, if the formation is negative, the formed is mazmuniah morals $^{13}$

Therefore al-Ghazali defines Akhlaq is a temperament (character) that resides in a person's soul and is the source of the arising of certain actions from himself easily and lightly without being thought out or planned beforehand ". 14

From some of the notions of education and character above, conclusions can be drawn, character education is a conscious effort by educators to learners to shape learners 'personalities that teach and shape good morals, ethics, and a sense of culture and noble character that foster students' abilities. Provided good and bad decisions and realize that goodness in everyday life by carrying out education, teaching, guidance and training.

The character education is not only the type of subjects, such as Islamic Religious Education (PAI), Moral Pancasila Education (PMP) or others, but the process of internalization or inculcation of positive values to students is more importan, they 1992), 51.

${ }^{9}$ Thomas Lickona, Educationg for Character, (Bantam Doubleday Dell Publishing Group Inc,

${ }^{10}$ Zubaedi, Desain Pendidikan Karakter, (Jakarta: Kencana Prenada Media, 2012), 65.

11 Zubaedi, 65.

12 Zubaedi, 66.

${ }^{13}$ Hamam Burhanuddin et al., "33 Model Pendidikan Islam Dengan Pendekatan Humanisme Religius (Studi Kasus Di MTs Attanwir Talun Sumberrejo, Bojonegoro)," Januari-Juni 01, no. 02 (2015): 2406-2775.

14 Zubaedi, 67. 
are have good (good character) in accordance with the values referenced, both from religion, culture, and state philosophy. ${ }^{15}$

The Character education in Islamic view is a conscious effort made by educators to students to form the personality of students who teach and shape good morals, ethics, and a sense of good morality that foster students' ability to make good and bad decisions and realize goodness in daily life by way of doing education, teaching, guidance and training which is guided by the Qur'an.

\section{B. VALUES IN CHARACTER EDUCATION}

From some of the above meanings, the character is identical with morals, so the character can interpreted as an embodiment of universal human behavioral values and includes all human activities, both the relationship between humans and God (hablumminallah), human relations with humans (hablumminannas) and human relationships with the environment.

These values formulated by the Ministry of National Education (2010) as quoted by Muhammad Kosim, which is 18 , values as follows:

1. Religious. Obedient attitudes and behaviors in implementing religious teachings, being tolerant of other religious practices, and living in harmony with followers of other religions.

2. Honesty. Behavior based on efforts to make himself as a person who can always be trusted in words, actions, and work.

3. Tolerance. Attitudes and actions that respect differences in religion, ethnicity, ethnicity, opinions, attitudes, and actions of others that are different from him.

4. Discipline. Actions that exhibit orderly behavior and comply with various rules and regulations.

5. Hard Work. Actions that exhibit orderly behavior and comply with various rules and regulations.

6. Creative. Think and do something to produce a new way or result from something you already have.

7. Independent. Attitudes and behaviors that are not easy depend on others in completing tasks.

8. Democratic. How to think, behave and act that assesses the same rights and obligations of himself and others.

9. Curiosity. Attitudes and actions that always strive to find out more deeply and extensively from something learned, seen, and heard.

10. National Spirit. A way of thinking, acting and having insight that places the interests of the nation and the state above self and group interests.

${ }^{15}$ Amirulloh Syarbini, Model Pendidikan Karakter dalam Keluarga, (Jakarta: Alex Media Komputindo, 2012), 18. 
11. Love the Motherland. A way of thinking, acting and having insight that places the interests of the nation and the state above self and group interests.

12. Appreciating Achievement. Attitudes and actions that encourage him to produce something that is useful for society, and acknowledge, and respect the success of others.

13. Friendly / Communicative. Attitudes and actions that encourage him to produce something that is useful for society, and acknowledge, and respect the success of others.

14. Peaceful Love. Attitudes and actions that encourage him to produce something that is useful for society, and acknowledge, and respect the success of others.

15. Likes to read. The habit of providing time to read various readings that provide virtue for him.

16. Care for the Environment. Attitudes and actions that always try to prevent damage to the surrounding natural environment, and develop efforts to repair natural damage that has already occurred.

17. Social Care. Attitudes and actions that always want to assist to other people and communities in need. ${ }^{16}$

18. Responsibility. The attitude and behavior of a person to carry out their duties and obligations, which he should do, towards oneself, society, environment (natural, social and cultural), the state and God Almighty.

\section{THE PURPOSE OF CHARACTER EDUCATION}

The purpose of character education according to Qur'an is to make a man of good character. In this case, the benchmark is the morality of the Prophet Muhammad and the basis of character formation is the Quran. However, we must realize that no human being has the same attitude as Prophet Muhammad.

As in Muttafaq's history hadith, here are the following:

"It's all right. It said, "Allah's Messenger (May peace be upon him), is the best person in his life." (Muttafaq alaih). ${ }^{17}$

From this hadith, it is very clear that the Messenger of Allah (May Peace Be upon Him) is proof that his conduct is perfect. This hadith also reinforces Bambang Q-Anees's (2009: 6) opinion of the Prophet Muhammad is the Quran, because in the Messenger of Allah there is the Quran and he never once did any deviation and deviated from the moral code.

The Quran is a guide for Muslims. As mentioned above when we want to direct our education and develop strong character in our students, we must emulate the character of the Prophet Muhammad who has the perfect character.

Word of Allah SWT.

"And verily you are truly virtuous." (Q.S. al-Qalam: 4)

\footnotetext{
${ }^{16}$ Burhanuddin, "Membangun Karakter Bangsa Melalui Pendidikan Islam."

17 Mustofa Said al-Khim, 2012: 695
} 
In character-based character education, we are obligated to do well and help each other and trained to be patient, to hold grudges and to forgive others as God Almighty says.

Meaning:

"... and those who hold back their anger and forgive people. God loves those who do good. " (Surat al-Imran: 134)

From the description above, the goal of character education according to Islam is to form a person of noble character, because noble character is the base of goodness. People of good character will soon do well and leave bad things.

In Islam, it is Muhammad SAW. has a great moral code: "wine la' ala khuluqin azim "(QS Al-Qalam: 4). The Prophet's exemplary virtues include maintaining, trusting, trusting, socializing and communicating effectively with humankind in his dignity and dignity, assisting others in their kindness, honoring guests, avoiding conflicts, understanding the values and norms, maintaining a balanced ecosystem, and consulting. In all matters of mutual interest. The existence of the Prophet as the messenger of God to humankind essence derived from his statement: "Verily, I (Muhammad) was sent to the world solely to fulfill the Morals of mankind" (alHadist). This human being must rely on all positive and commendable actions. That is all part of a noble act. In Islam, the moral code is very important, it is the "fruit" of the Islamic tree of faith and the leaves of Shari'ah.

Muhammad sent to perfect the moral, undeniable. He was a figure who maintained the tradition, then melted or accommodated it better than before. As evidence of this, the Prophet changed the tradition of midnight eating to end, tradition of grave pilgrimage, tradition of asthma fasting, rajab, sa'ban, dahr, etc.

Thus, the position of character values occupies a high position in the Qur'an and the Hadith, even as the soul, substance and mission of the teachings of the Qur'an and the Hadith. In other words, all the teachings in Islam that God passed on to his Prophet to shape human character. Aqidah, worship and worship are not the goal, but as a conveyor to the perfect human, muttaqie / character.

\section{CHARACTER EDUCATION STRATEGY}

In the eyes of Muslims, destructive symptoms in society are due to the loss of Islamic character and personality. We are addicted to Western products that are hedonistic, completely free and oriented to worldly pleasures. The permissive concept has the effect of damaging the structure of social life, disrupting morality and diminishing the value of togetherness between individuals.

Obviously, this conception is contrary to the Islamic values governing tawazun (balance) world life and the hereafter. Rasulullah SAW in forming the chosen generation greatly intensified the three intelligences namely emotional, spiritual and intellectual. The result can felt where many great Islamic fighters were born such as Abu Bakr, Umar, Usman, Ali and other companions. There are several strategic principles in shaping the character of the Prophet to his friends as his successors. 
First, Rasulullah SAW focused on developing and preparing cadres. In fact can be seen since he began to get the mandate of $d a^{\prime} w a h$. The task of spreading Islam is carried out by finding the seeds of superior leadership with clean hearts. His da'wah focus did not touch aspects of Makkah's political life. In addition to instability and political power, the propaganda struggle is indeed focused on the value of coaching. He tried to instill the prophetic character of siddiq (honest), trustful (trustworthy), tabligh (convey) and fatonah (intelligent). Arqam bin Abil Arqam's house witnessed how the Islamic leadership was finally born. The first important point of character education is the focus, gradual and consistent towards early development.

Second, giving priority to the language of action is better than words. Ayesha called Rasulullah SAW as the Qur'an that goes. The term is not wrong; looking at Sirah Nabawiyah makes us reap the awareness of the reconstruction of the thoughts and actions of the Prophet Muhammad. He did first, and then called on his people to follow him. Individual piety succeeded in forming collective piety in the communities of Makkah and Medina.

"Indeed, the Prophet himself. There are examples of examples for those who hang their hopes on Allah and the Hereafter and do many dhikr of Allah "(QS 33: 21). When preaching in the Thaif community he got bad treatment stoned. At that moment, Angel Gabriel came to offer services. "O Muhammad, if you want the mountain in front of you for me to pour over the people of Thaif, surely I will also do it now." "lamûn" "O Allah, give guidance to my people, indeed they do not know" Thank God, Allah SWT heard his prayer, the Thaif people became many followers of Islam. The second important point, give a new example to invite others to follow what we do.

Third, instilling beliefs is ideological to produce moral and ethical values in changing society. He straightened their polytheism by teaching the phrase monotheism that is to believe in God as the only God entitled to worship. The character of monotheism produces human movements based on Islamic law in running life. The most important character education is moral and ethical education. Rasulullah SAW himself emphasized this in his saying, "I was only sent to perfect the morality of the mercy." (Ahmad and others). Regrown morality should be a competence in the process of character education for every nation.

Finally, the character must integrate cognitive, affective and psychomotor aspects. Rasulullah SAW has set the example by building moral and ethical-based education. Educational development started from Pesantren, Campus and School as a fertile ground for coaching as well as empowering the character of the younger generation. Because with good morals and ethics that are based on true ideology will form the nation's community that rahmatan lil alamin. Character education also accommodates various philosophical ideas of human beings, which have been institutionalize in traditions, customs, habits, decisions, cultural values and local wisdom in accordance with the Qur'an and Hadith. 
then it is very clear the urgency or importance of character education at this time because the character will show who we really are, character will determine how someone makes decisions, the character determines the attitudes, words and deeds of someone, people who have good character, then the words and deeds will also definitely be good, so that all of it will become a unified identity and personalize towards him, so it is easy to distinguish from other identities.

\section{E. CONCLUSION}

Character education consists of two words namely education and character. The meaning of character education according to Islam is a conscious effort made by educators to students to shape the personality of students who teach and shape morals, ethics, and a good sense of culture. good character that foster students' ability to make good and bad decisions and realize goodness that in everyday life by means of education, teaching, guidance and training which is guided by the Qur'an.

The basis of character education in Islam is the Qur'an the character of the Prophet Muhammad. The character education is very important at this time, because character will show who we really are, character will determine how someone makes decisions, character determines attitudes, words and actions of someone, people who have good character, then the words and deeds will also be good, so all it will become a unified identity and personalize itself, making it easy to distinguish from other identities.

The purpose of character education is to form a person of noble character, because noble character is the base of goodness. People of good character will soon leave goodness and leave badness. Implementation of character education in Islamic educational institutions varies greatly depending on the policies of these educational institutions. 


\section{DAFTAR PUSTAKA}

Burhanuddin, Hamam. "Membangun Karakter Bangsa Melalui Pendidikan Islam." At-Tajdid : Jurnal Ilmu Tarbiyah, 2014.

Burhanuddin, Hamam, Staf Pengajar, Stit Islamiyah, Karya Pembangunan, and Paron Ngawi. "33 Model Pendidikan Islam Dengan Pendekatan Humanisme Religius (Studi Kasus Di MTs Attanwir Talun Sumberrejo, Bojonegoro)." Januari-Juni 01, no. 02 (2015): 2406-2775. Kamus Besar Bahasa Indonesia, 2012.

Lickona, Thomas, Educationg for Character, (Bantam Doubleday Dell Publishing Group Inc, 1992). Marzuki, Pendidikan Karakter Islam, (Jakarta: Amzah, 2015).

Sudrajat, Ajat. “Mengapa Pendidikan Karakter?” Jurnal Pendidikan Karakter 1, no. 1 (2011): 4758. https://doi.org/10.21831/jpk.v1i1.1316.

Syarbini, Amirullah, Pendidikan Karakter Berbasis Keluarga, (Jakarta: Arruz Media, 2012), 15.

Zubaedi, Desain Pendidikan Karakter, (Jakarta: Kencana Prenada Media, 2012) 